\title{
Implications Of The Selection Of A Method To Allocate State Income Taxes In Order To Determine Net Foreign-Source Income
}

\author{
Robert M. Kozub, University of Wisconsin-Milwaukee, USA
}

\begin{abstract}
Internal Revenue Code Sections 861-864 determine the source of income and Sections 861(a) and 862(a) specifically allocate certain items of gross income to sources within or without the United States. Sections 861(b) and 862(b) state generally how to determine taxable income for a taxpayer with income sources within or without the United States after such source has been determined. Regulation \$ 1.861-8 provides more information on allocating state and local taxes to U.S. - and foreign-source income. Regulation $\$ 1.861-8$ is based on the factual relationship of deductions to gross income test. This Regulation provides a concise rule requiring that the deduction for state, local, and foreign income, war profits, and excess profits taxes under Section 164 are definitely related and allocable to the gross income with respect to which such taxes are imposed. Under Regulation $\$ 1.861(e)(6)$ if foreign-source of a corporation related by ownership to a corporate taxpayer is attributed to the activities conducted by the taxpayer in a state and is subject to state income tax, as in a state unitary income tax, the state tax deduction is allocable to the foreign-source income of the related corporation for purposes of the foreign tax credit used $\$ 904$. This paper first considers the most common methods for allocating state income taxes, the presumptive, analytic, and state-by-state methods. In the Chevron case, the Tax Court was asked to consider whether any of the following methods comply with the regulations; these methods are the gross income, factor operations, statutory notice, the pro rata, and the example methods. This paper will also consider the requirements and validity of related regulations.
\end{abstract}

Key words: Foreign Tax Credit, Allocation, State Income Taxes

\section{INTRODUCTION}

Q nder U.S. tax law different tax treatments are accorded taxpayers based on their country of citizenship or country of organization. The United States taxes its citizens, resident aliens, ${ }^{1}$ and domestic corporations ${ }^{2}$ on their worldwide income, and in general, the same income tax rules apply to all citizens, resident aliens, and domestic corporations regardless of where it is earned. The foreign tax credit was enacted to permit U.S. taxpayers to avoid double taxation by crediting income taxes paid or accrued in a foreign country, including political subdivisions such as provinces and cities, or a U.S. possession ${ }^{3}$ against the U.S. income tax liability. In effect the foreign tax credit reduces a U.S. taxpayer's total worldwide tax rate on income earned in foreign countries or U.S. possessions to the higher of the U.S. or foreign tax rates. The foreign tax credit, however, is limited to prevent the credit from being used to prevent taxes levied on income earned in the United State. This limit sets the maximum foreign tax credit that may be claimed by the U.S. taxpayer. The maximum foreign tax credit is the portion of the gross U.S. tax liability originating from foreign source taxable income and is calculated as follows:

Overall foreign tax credit limitation $=$ U.S. tax liability X $\underline{\text { Taxable income from all foreign countries }}$

Total worldwide taxable income 
The foreign tax credit is the lesser of (1) the creditable taxes paid or accrued to all foreign countries and U.S. possessions or (2) the overall foreign tax credit limitation. The overall limitation permits taxpayers to offset excess foreign taxes paid in one country against excess limitation amounts that result from activities in other countries during the same tax year. The total foreign taxes paid or accrued on foreign source taxable income may not exceed the total U.S. due on such income.

With the passage of the Tax Reform Act of 1986, the United States became a "low tax" country. One result of this change is that multi-national corporations will find that they have excess foreign tax credits. As a result of these reductions in federal income tax rates corporations will attempt to maximize their foreign-source income and to minimize the expenses apportioned to foreign-source income in order to use the foreign tax credits. Treasury Regulation Section 1.861-8 governs the apportionment of expenses between U.S.- and foreign-source income. The apportionment methods for state income taxes are complex and each method results in a different amount being apportioned to foreignsource income.

In this regard, it is important for corporations to review their methods of apportioning state income taxes between U.S.- and foreign-source income for foreign tax credit purposes. Since several apportionment methods are allowable there will be significant differences when comparing different methods. Another state tax that must be apportioned is state franchise taxes; these taxes are imposed on corporations by many states on the privilege of conducting business in those states and are often viewed as analogous to state income taxes.

\section{Overview of State Income Tax Apportionment}

Three methods for apportioning state income taxes are permitted: the presumptive, analytic, and state-by-state methods. The regulation stated that state income taxes were considered to be "definitely related and allocable to the gross income with respect to which the taxes are imposed" and the Regulation Section 1.861-8(e)(6)(i) restated this general principle. The regulation provided that taxpayers should use the method of apportionment that produces the most accurate result. Therefore, corporations should review their methods and select the apportionment method that is both supportable and advantageous.

\section{Apportionment Methods}

Each of the three apportionment methods, the presumptive, analytic, and state-by-state methods, is based on different assumptions. The presumptive method is the standard method used in apportioning state income tax expenses. It assumes that the states tax only income from domestic sources; any excess of state taxable income over U.S.-source income is assumed to be foreign-source income. ${ }^{4}$

The analytic method requires an analysis of the actual U.S.- and foreign-source income taxed by the states. The proportion of U.S.-source income and foreign-source income taxed by the states apportions the total state income tax liability. In a Private Letter Ruling, the Internal Revenue Service promoted the use of the analytic method over the presumptive approach by stating that the presumption that states only tax U.S.-source income is operative only in rare circumstances. ${ }^{5}$ Generally, taxpayers can determine the foreign-source income that can be taxed by state law. In the regulation, however, use of the presumptive method appears to be accepted by the IRS as the primary method for apportioning state income taxes. The state-by-state apportionment method is a variation of the analytic method whereby the taxpayer analyzes the actual U.S.-source and foreign-source income taxed by each state. Each state's actual income tax liability is apportioned to U.S.-source and foreign-source income, in proportion to total taxable income.

These three apportionment methods are the most common methods for apportioning the state income tax expense; other methods may be used if the taxpayer established, to the satisfaction of the District Director, that the different method produces a more accurate apportionment of state income taxes. ${ }^{6}$ Exhibit 1 illustrates the results that are obtained from applying the - presumptive, analytic, and state-by-state apportionment methods. Using the same basic fact the analytic and the state-by-state methods result in the same amount of state income tax being apportioned to both the U.S.-source and foreign-source income. Exhibit 2 illustrates the same apportionment methods, using the facts in Exhibit 1 except that the apportionment percentage for State A was increased. In this situation, the methods apportion a 
different amount of state income tax to U.S.- and foreign-source income. The comparison of the two illustrations shows that the apportionment approach that results in the lowest apportionment of state income tax expense to foreign-source income depends on the particular facts of the situation. Thus, a taxpayer with foreign-source income should determine on a multi-year basis which method results in the lowest apportionment, given the taxpayer's unique fact pattern, before selecting a method for income tax purposes. Taxpayers may use any of the three methods discussed. If they use a different method, they must prove that it results in a more accurate apportionment of state income taxes than other methods. The ultimate selection of an apportionment method must be supportable. ${ }^{7}$

Exhibit 1: Illustration of Allocation Methods

\begin{tabular}{|c|c|c|c|c|c|}
\hline & $\begin{array}{c}\text { U.S. } \\
\text { Source } \\
\text { Income }\end{array}$ & $\begin{array}{c}\text { Foreign- } \\
\text { Source } \\
\text { Income }\end{array}$ & $\begin{array}{l}\text { Federal } \\
\text { Taxable } \\
\text { Income }\end{array}$ & $\begin{array}{c}\text { State } \\
\text { Taxable } \\
\text { Income }\end{array}$ & $\begin{array}{c}\text { State Tax } \\
\text { Liability }\end{array}$ \\
\hline State A & $\$ 100,000$ & $\$ 50,000$ & $\$ 150,000$ & & \\
\hline Adjustments & 20,000 & & & & \\
\hline State A Adjusted Taxable Income & 120,000 & 50,000 & & & \\
\hline Apportionment Percentage & .30 & .30 & & & \\
\hline State A Taxable Income & $\$ 36,000$ & $\$ 15,000$ & & $\$ 51,000$ & \\
\hline State A Tax Liability (10\%) & & & & & $\$ 5,100$ \\
\hline State B & $\$ 100,000$ & $\$ 50,000$ & & & \\
\hline Adjustments & $(5,000)$ & & & & \\
\hline State B Adjusted Taxable Income & 95,000 & 50,000 & & & \\
\hline Apportionment Percentage & .40 & .40 & & & \\
\hline State B Taxable Income & $\$ 38,000$ & $\$ 20,000$ & & $\$ 58,000$ & \\
\hline State B Tax Liability $(10 \%)$ & & & & & $\$ 5,800$ \\
\hline Total Taxable Income State A \& B & & & & $\$ 109,000$ & \\
\hline Total State Tax Liability State A \& B & & & & & $\$ 10,900$ \\
\hline
\end{tabular}

\section{PRESUMPTIVE METHOD}

This method compares total taxable income for States A and B (\$109,000) with U.S.-Source Income $(\$ 100,000)$. The $\$ 9,000$ excess is presumed to be Foreign-Source Income. Therefore, allocation of the total state tax liability of $\$ 10,900$ is as follows:

\begin{tabular}{|lclll|}
\hline U.S.-Source & $\$ 100,000$ & $X$ & $\$ 10,900$ & $=\$ 10,000$ rounded \\
\cline { 2 - 3 } & $\$ 109,000$ & & \\
\hline Foreign-Source & $\frac{\$ 9,000}{\$ 109,000}$ & & $\$ 10,900$ & \\
& & & & \\
\hline
\end{tabular}

\section{ANALYTIC METHOD}

This method analyzes the actual U.S.-Source and Foreign-Source Income taxed by each state as follows:

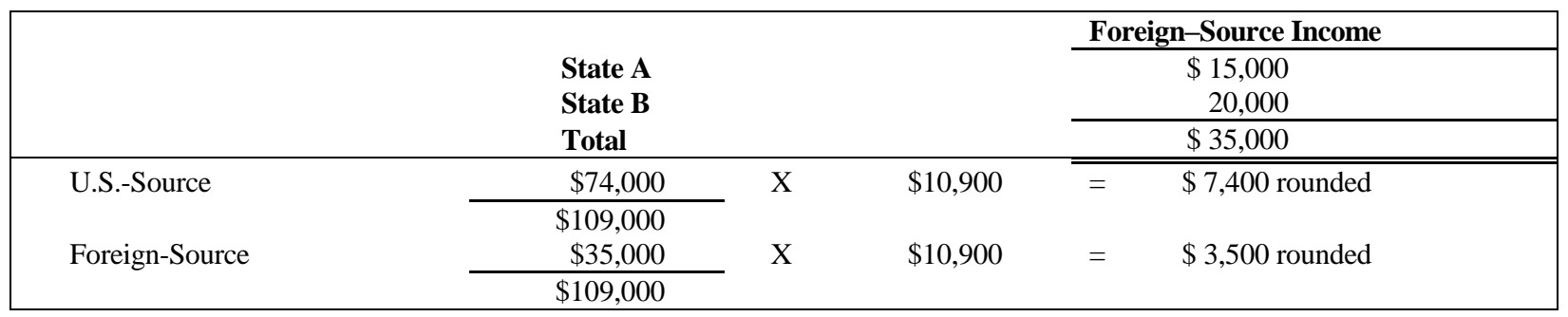




\section{STATE-BY-STATE METHOD}

This method analyzes actual U.S.-Source and Foreign-Source Income taxed by each state as follows:

\begin{tabular}{|c|c|c|c|c|}
\hline State & $\begin{array}{c}\text { U.S.-Source Income } \\
\text { Apportioned To State } \\
\text { (1) }\end{array}$ & $\begin{array}{c}\text { Foreign.-Source Income } \\
\text { Apportioned To State } \\
\text { (2) }\end{array}$ & $\begin{array}{l}\text { Total Taxable } \\
\text { Income } \\
(3) \\
\end{array}$ & $\begin{array}{c}\text { Tax Liability } \\
\text { (4) }\end{array}$ \\
\hline $\mathrm{A}$ & $\$ 36,000$ & $\$ 15,000$ & $\$ 51,000$ & $\$ 5,100$ \\
\hline $\mathrm{B}$ & 38,000 & 20,000 & 58,000 & 5,800 \\
\hline \multicolumn{2}{|l|}{ State } & $\begin{array}{l}\text { Tax Liability Allocated to } \\
\text { U.S.-Sources (1) X [(4)/(3)] }\end{array}$ & \multicolumn{2}{|c|}{$\begin{array}{l}\text { Tax Liability Allocated to } \\
\text { Foreign-Sources (2) X [(4)X(3)] }\end{array}$} \\
\hline \multicolumn{2}{|l|}{$\mathrm{A}$} & $\$ 3,600$ & \multicolumn{2}{|c|}{$\$ 1,500$} \\
\hline \multicolumn{2}{|l|}{$\mathrm{B}$} & 3,800 & \multicolumn{2}{|c|}{2,000} \\
\hline \multicolumn{2}{|c|}{ Total U.S.-Source State Tax } & $\$ 7,400$ & \multirow{2}{*}{\multicolumn{2}{|c|}{$\$ 3,500$}} \\
\hline \multicolumn{2}{|c|}{ Total Foreign-Source State Tax } & & & \\
\hline
\end{tabular}

\section{EXHIBIT 2}

\section{ILLUSTRATION OF ALLOCATION METHODS}

The facts in this Exhibit are the same as in Exhibit 2 with the exception that the apportionment percentage for State A is now 35\% instead of 30\% used in Exhibit 1.

\begin{tabular}{|c|c|c|c|c|c|}
\hline & $\begin{array}{l}\text { U.S. Source } \\
\text { Income }\end{array}$ & $\begin{array}{c}\text { Foreign- } \\
\text { Source } \\
\text { Income } \\
\end{array}$ & $\begin{array}{l}\text { Federal } \\
\text { Taxable } \\
\text { Income }\end{array}$ & $\begin{array}{l}\text { State Taxable } \\
\text { Income }\end{array}$ & $\begin{array}{c}\text { State } \\
\text { Tax } \\
\text { Liability }\end{array}$ \\
\hline State A & $\$ 100,000$ & $\$ 50,000$ & $\$ 150,000$ & & \\
\hline Adjustments & 20,000 & & & & \\
\hline State A Adjusted Taxable Income & 120,000 & 50,000 & & & \\
\hline Apportionment Percentage & .35 & .35 & & & \\
\hline State A Taxable Income & $\$ 42,000$ & $\$ 17,500$ & & $\$ 59,500$ & \\
\hline State A Tax Liability (10\%) & & & & & $\$ 5,950$ \\
\hline State B & $\$ 100,000$ & $\$ 50,000$ & & & \\
\hline Adjustments & $(5,000)$ & & & & \\
\hline State B Adjusted Taxable Income & 95,000 & 50,000 & & & \\
\hline Apportionment Percentage & .40 & .40 & & & \\
\hline State B Taxable Income & $\$ \quad 38,000$ & $\$ 20,000$ & & $\$ 58,000$ & \\
\hline State B Tax Liability (10\%) & & & & & $\$ 5,800$ \\
\hline Total Taxable Income State A \& B & & & & $\$ 117,500$ & \\
\hline Total State Tax Liability State A \& B & & & & & $\$ 11,750$ \\
\hline
\end{tabular}

\section{PRESUMPTIVE METHOD}

This method compares total taxable income for States A and B $(\$ 117,500)$ with U.S.-Source Income $(\$ 100,000)$. The $\$ 17,500$ excess is presumed to be Foreign-Source Income. Therefore, allocation of the total state tax liability of $\$ 11,750$ is as follows:

\begin{tabular}{|c|c|c|c|c|c|}
\hline \multirow[t]{2}{*}{ U.S.-Source } & $\$ 100,000$ & \multirow[t]{2}{*}{$\mathrm{X}$} & \multirow[t]{2}{*}{$\$ 11,750$} & \multirow[t]{2}{*}{$=$} & \multirow[t]{2}{*}{$\$ 10,000$ rounded } \\
\hline & $\$ 117,500$ & & & & \\
\hline \multirow[t]{2}{*}{ Foreign Source } & $\$ 17,500$ & $\mathrm{X}$ & $\$ 11,750$ & $=$ & $\$ 1,750$ rounded \\
\hline & $\$ 117,500$ & & & & \\
\hline
\end{tabular}




\section{ANALYTIC METHOD}

This method analyzes the actual U.S.-Source and Foreign-Source Income taxed by each state as follows:

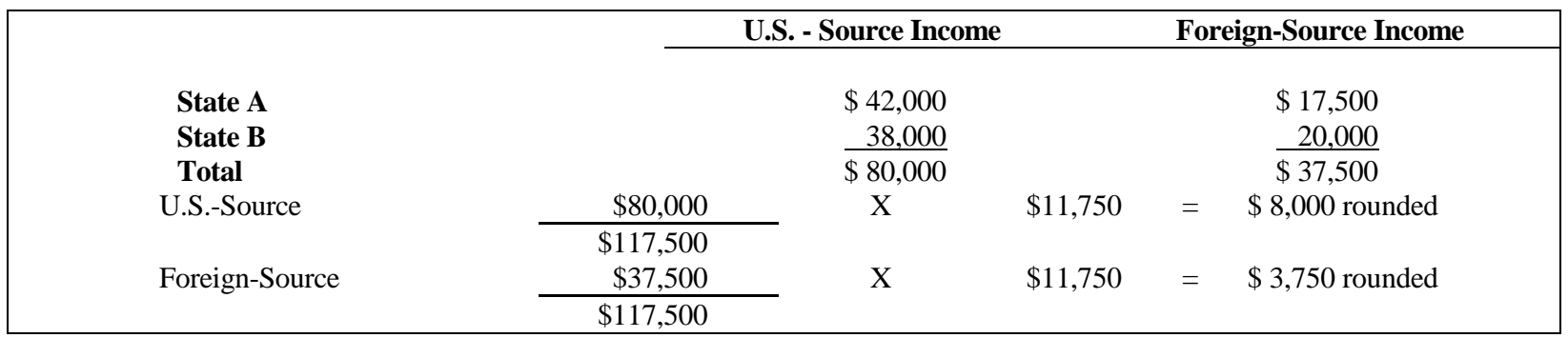

\section{STATE-BY-STATE METHOD}

This method analyzes actual U.S.-Source and Foreign-Source Income taxed by each state as follows:

\begin{tabular}{|c|c|c|c|c|}
\hline State & $\begin{array}{l}\text { U.S.-Source } \\
\text { Income } \\
\text { Apportioned } \\
\text { To State } \\
\text { (1) } \\
\end{array}$ & $\begin{array}{c}\text { Foreign.-Source } \\
\text { Income } \\
\text { Apportioned To } \\
\text { State } \\
\text { (2) } \\
\end{array}$ & $\begin{array}{c}\text { Total Taxable } \\
\text { Income } \\
(3)\end{array}$ & $\begin{array}{c}\text { Tax Liability } \\
\text { (4) }\end{array}$ \\
\hline $\bar{A}$ & $\$ 42,000$ & $\$ 17,500$ & $\$ 59,500$ & $\$ 5,950$ \\
\hline B & 38,000 & 20,000 & 58,000 & 5,800 \\
\hline State & & \multicolumn{2}{|c|}{$\begin{array}{l}\text { Tax Liability } \\
\text { Allocated to } \\
\text { U.S.-Sources } \\
\text { (1) X [(4)/(3)] }\end{array}$} & $\begin{array}{l}\text { Tax Liability } \\
\text { Allocated to } \\
\text { Foreign-Sources } \\
\text { (2) } \mathrm{X}[(4) \mathrm{X}(3)]\end{array}$ \\
\hline A & & \multicolumn{2}{|c|}{$\$ 4,200$} & $\$ 1,750$ \\
\hline $\mathrm{B}$ & & \multicolumn{2}{|c|}{3,800} & 2,000 \\
\hline Total U. & & \multirow{2}{*}{\multicolumn{2}{|c|}{$\$ 8,000$}} & \\
\hline Total Fo & & & & $\$ 3,750$ \\
\hline
\end{tabular}

Negative Apportionment

Under certain circumstances it is possible for a taxpayer to have a negative apportionment of state income tax to foreign-source income under the presumptive method of apportionment. This situation is illustrated in Exhibit 3. Such results occur when the total income taxed by the states is less than the U.S.-source income. In this case, the U.S.source income will have apportioned to it more than the total state tax liability. Foreign-source income will be considered to be negative, and will have a negative amount of state income tax apportioned to it. If the negative apportionment were allowed, foreign-source income would be increased by the negative expense apportioned to it. In effect, the corporation would be able to utilize more of its foreign tax credits.

\section{EXHIBIT 3: ILLUSTRATION OF NEGATIVE ALLOCATION}

\begin{tabular}{|lccccc|}
\hline & $\begin{array}{c}\text { U.S. Source } \\
\text { Income }\end{array}$ & $\begin{array}{c}\text { Foreign-Source } \\
\text { Income }\end{array}$ & $\begin{array}{c}\text { Federal Taxable } \\
\text { Income }\end{array}$ & $\begin{array}{c}\text { State } \\
\text { Taxable Income }\end{array}$ & $\begin{array}{c}\text { State Tax } \\
\text { Liability }\end{array}$ \\
\hline State A & $\$ 100,000$ & $\$ 50,000$ & $\$ 150,000$ & & \\
Adjusted & & & & & \\
Taxable Income & 120,000 & 50,000 & & & \\
Apportionment Percentage & & & & $\$ 85,000$ & \\
Taxable Income & .50 & .50 & & \\
State A Tax Liability (10\%) & $\$ 60,000$ & $\$ 25,000$ & & & \\
\hline
\end{tabular}




\section{PRESUMPTIVE METHOD}

This method compares total taxable income for States A $(\$ 85,000)$ with U.S.-Source Income $(\$ 100,000)$. The difference of negative $\$ 15,000$ is presumed to be foreign source income. Therefore, allocation of the total state tax liability of $\$ 8,500$ is as follows:

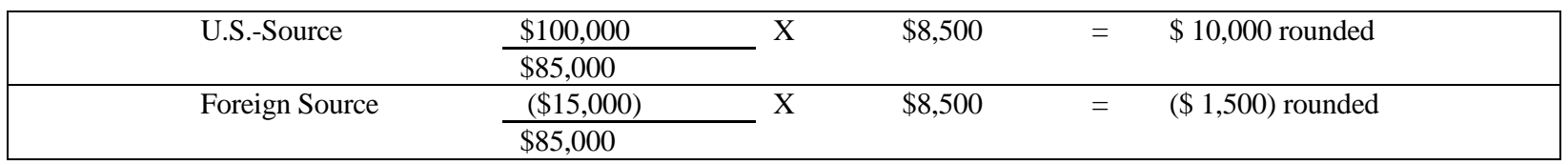

According to the IRS, ${ }^{8}$ the apportionment of a negative state income tax expense to foreign-source income is not authorized by either the regulations ${ }^{9}$ or the Code. ${ }^{10}$ While a Letter Ruling has no presidential value, it does indicate the IRS' opposition to negative apportionment. This opposition was stated again in the regulations on allocation and apportionment of deductions for state income taxes that disallow negative apportionment. Specifically, the regulations state if:

...the total amount of state income is less than or equal to the amount of U.S. income for Federal income tax purposes, none of the state income tax is allocable to a class of income that includes foreign source income. ${ }^{11}$

\section{Unitary Taxation}

The apportionment methods illustrated above were performed on the non-combined reporting basis, the apportionment of a state tax liability may be calculated on the unitary basis. Taxpayers subject to a unitary method of state income taxation should review their approach to the apportionment of state income taxes for two reasons. First, unitary tends to increase the state income tax expense. Second, the inclusion of profitable foreign subsidiaries in the unitary business group tends to increase the amount of foreign-source income. Therefore, corporations will be able to utilize more of their foreign tax credits.

\section{Revenue Rulings}

In 1987, two revenue rulings dealing with the apportionment of state franchise taxes between U.S.- and foreign-source incomes were issued. The deductibility of state franchise taxes payable by a foreign (non-U.S.) corporation when the franchise tax is imposed on income effectively connected to a U.S. trade or business and on income not effectively connected to a U.S. trade or business was addressed in Revenue Ruling 87-64. ${ }^{12}$ Allocation of a state franchise tax payable by a domestic corporation for purposes of calculating foreign-source taxable income for the foreign tax credit limitation under Section 904 was discussed in Revenue Ruling 87-65. ${ }^{13}$ In 1988, the Treasury issued regulations that prescribe the allocation and apportionment rules for state, local, and foreign income taxes; war profits taxes; and excess profits taxes. ${ }^{14}$ Included in the regulation are examples of the methods of allocation and apportionment of the listed taxes. ${ }^{15}$ The portion of the regulation specifying that the deduction for state income tax and state franchise tax should be considered definitely related and allocable to gross income with respect to which such taxes are imposed is effective for tax years beginning after December $31,1976 .{ }^{16}$ The portions of the regulations pertaining to the methods of allocation and apportionment by means of examples are effective for tax years beginning on or after January 1, 1988, although taxpayers may have utilized those methods in prior years.

\section{Revenue Ruling 87-64}

Revenue Ruling 87-64 dealt with a foreign corporation in State A that levies both an income and a franchise tax. Under State A's franchise tax, the tax is calculated by multiplying a corporation's allocable net income by a stated tax rate. The allocable net income is the sum of business and investment income allocated to the state using a threefactor apportionment formula. This three-factor apportionment formula is also used for income allocation under the state's income tax. 
State A includes foreign-source portfolio dividends in its definition of business income, even though the dividends may not be effectively connected to an U.S. trade or business for federal income tax purposes. As a result of being included in business income, the foreign-source portfolio dividends are subject to State A's three-factor apportionment formula. The state apportionment formula does not include any factors pertaining to the foreign corporation paying the dividend. As a result the foreign-source dividends increase the taxpayer's net income subject to tax beyond the amount subject to tax for federal income tax purposes, which, in the case of a foreign corporation, excludes from the tax base income not effectively connected to a U.S. trade or business.

At issue in this ruling was how this state's franchise tax should be allocated for federal income tax purposes to the foreign corporation's effectively connected income. According to a previous revenue ruling, the IRS held that in this type of situation the franchise tax is deductible in full against the foreign corporation's effectively connected income. ${ }^{17}$ The prior revenue ruling was based on an analysis of the New York' State corporate franchise tax. Since the New York State definition of worldwide net income may include amounts not effectively connected with a U.S. trade or business, the IRS ruled that the allocation rules of Regulation Section 1.861-8 do not apply and the franchise tax was attributed solely to the gross income generated by the corporation's effectively connected income. As support for its position the IRS stated that Regulation Section 1.861-8 applies to income taxes, not franchise taxes.

The IRS issued Revenue Ruling 87-64 to revoke Revenue Ruling 79-186, then the regulations specifically states that all state taxes imposed on state taxable income will be treated as an income tax regardless of the relationship to it by the state. ${ }^{18}$ The franchise tax levied in State A, as well as many other states, is computed in the same manner as an income tax, and it would be classified as an income tax under the regulations. ${ }^{19}$ The only difference between the two types of taxes is that an income tax is a tax on income, whereas a franchise tax is a tax imposed on the right to do business in a state and in some states is measured by income. In Revenue Ruling 87-64, the IRS determined that a corporate franchise tax imposed on a foreign (non-U.S.) must be apportioned between effectively connected and noneffectively connected income. This result is now achieved under the regulations.

As a result of Revenue Ruling 87-64, the net effectively connected income of a foreign corporation is subject to taxation in the United States was significantly increased as compared to the results under Revenue Ruling 79-186. The reasoning for the determination in Revenue Ruling 87-64 was incorporated in Regulation Section 1.861-8T(e)(6). In Example 28 of the Regulation, a portion of the state franchise tax is definitely related to the portfolio dividends and must be allocated to the class of gross income consisting of foreign-source portfolio dividends. The remaining state tax is allocated and apportioned under the general presumptive method.

Revenue Ruling 87-65

The effect of state franchise taxes, measured by income on domestic corporations with operations in foreign countries for purposes of the foreign tax credit limitation under Section 904, was considered in Revenue Ruling 87-65. In this Revenue Ruling, a domestic (U.S.) corporation that operates in a state that levies both an income and a franchise tax is measured by the corporation's net state taxable income. Under Revenue Ruling 87-65, the franchise tax must be allocated between the U.S.- and foreign-source income in computing the Section 904 foreign tax credit limitation. In support of this position, the IRS states that regulations require those expenses must be allocated and apportioned on the basis of factual relationships of expenses to gross income. ${ }^{20}$ Allocation of a deduction is made by first determining the activity from which the deduction resulted, then, the deduction is allocated to the class of gross income generated by that activity. ${ }^{21}$ The reasoning behind Revenue Ruling 87-65 was incorporated into Regulation Section 1.861(e)(6). The extent to which a domestic corporation was effected by Revenue Ruling 87-65 and the changes in regulations depends on how the company treated franchise taxes in the past. If the corporation has allocated franchise taxes solely to foreignsource income, the required allocation between U.S.- and foreign-source income will increase foreign-source income, thereby increasing the allowable foreign tax credit. On the other hand, if a corporation has allocated franchise taxes solely to U.S.-source income. Allocation of the franchise tax decreased the net foreign-source income and the possibility of utilizing foreign tax credits. 


\section{New Regulations}

New rules for allocating the state income tax expense for purposes of calculating the foreign tax credit limitations were added in 1988 by modifying the existing regulations. Under this regulation, both a state income tax and a state franchise tax calculated on income must be considered as being definitely related and allocable to the gross income upon which such taxes are imposed in tax years beginning on or after January 1, 1988. ${ }^{22}$ This regulation considers the presumptive method to be the refutable correct method for allocating state taxes, and uses this method in Examples 25 through 29, which were based on Examples 25 and 26 of the old regulation. However, Examples 25 through 29 were designed to include the separate statutory groupings ("baskets") for the foreign tax credit limitation purposes as prescribed by the Tax Reform Act of 1986. This method was illustrated in Exhibits 1 and 2.

In applying the presumptive approach, neither the U.S.-source nor the foreign-source income can be reduced by the amount of the state income tax deduction that is being allocated. Although it is possible to have a negative allocation of state income tax to foreign-source income under the presumptive method of allocation (i.e., when the total income taxed by the states is less than the U.S.-source income), the regulation does not permit negative allocation.

\section{Foreign Tax Credit}

In calculating the foreign tax credit limitations, the allocation of state income tax expenses to U.S.- and foreignsource income requires that two modifications must be made. First, if the taxpayer operates in a state that exempt foreign-source income from state taxation, that state tax must be allocated to U.S.-source income. The U.S.-source taxable income is reduced by the tax attributable to the activities in the no-tax states. Next, the remaining state tax is allocated between U.S.- and foreign-source income. These results in the amount of state tax expense used to reduce both the U.S.-source and foreign-source income for federal income tax purposes.

In order to calculate the foreign-tax credit under the presumptive method, a separate allocation of state income tax expense to foreign-source income must first be made to any identifiable class of income with special state income tax treatment. Only then is the remainder of the state tax allocated and apportioned under the general principles of the presumptive method. This procedure is illustrated in Example 28 of the new regulation, which considers as apportionable state income, portfolio dividends from a foreign corporation that generate a portion of the state tax expense. The state, in this example, applies its tax to apportionable income including dividends, and its apportionment formula excluding any reference to the foreign corporation paying the dividends.

Before allocating any class of the tax to an identifiable class of income, each state's tax structure must be analyzed to properly calculate the amount of tax expense for each state. Since a number of states impose their income tax on the unitary basis, these states must be considered separately in order to determine the portion of the liability attributable to each corporation in the unitary group. ${ }^{23}$ In the regulation, Example 29 considers the effects on the allocation of state taxes when a state imposes its income tax on a worldwide unitary basis. In effect, the state tax liability is calculated as if the parent company had filed a separate return, and as if the U.S. companies generating the U.S.source income had filed a water's-edge return including redetermininng apportionment factors and on a world-wide unitary basis. If the worldwide unitary tax is greater than the "as if" separate company tax, the excess should be allocated. First, the excess of the worldwide unitary tax over the water's edge tax should be allocated to foreign-source income brackets, based on the type of income generated by the foreign entities, then any remaining water's-edge liability over the "as if" separate company liability should be allocated to the other U.S. entities.

\section{The Chevron Decision}

In its Chevron Corporation decision, the Tax Court considered the issue of apportioning or allocating state income taxes between U.S.- and foreign-source income under Code Sections 861(b) and 862(b). ${ }^{24}$ In this case, the court considered five allocation methods, three presented by the taxpayer, Chevron, and two presented by the Internal Revenue Service. These methods are the gross income method (Chevron's return method), factor operations method (Chevron's refund method), statutory notice method (IRS deficiency notice method), the pro rata method (IRS alternative method), and the example method (Chevron's fallback method). 


\section{The Gross Income Method Used By Chevron}

On its consolidated income tax returns, the Chevron group members allocated and apportioned the California's state income tax between U.S.- and foreign-source income by the gross income method. Using intrastate apportionment, the California income tax of group members was determined, followed by their U.S.- and foreign-source income. Finally, the California tax was apportioned between the members' US.- and foreign-source gross income in proportion to the ratio of such income to total gross income.

\section{The Factor Operations Method Used By Chevron}

When filing its claim for a refund, the Chevron group increased the state and local income and franchise taxes apportioned to U.S.- source gross income due to the application of the factors operations methods. As with the gross income method, intrastate apportionment was used to determine the California tax of each group member, followed by the determination of the U.S.- and foreign-source gross income of each member. Finally, each California apportionment factor was analyzed to determine the gross income from U.S. or foreign sources that such factors generated or reasonably could be expected to generate. If the gross income generated by the California factors of a group member was U.S.- or foreign-source-income, the California state tax of that member was apportioned entirely to such income. If it was neither entirely U.S.- or foreign-source income, the tax on that member would be apportioned to U.S.-source gross income based on the ratio of the member's California factors generating such income to the member's total California factors.

\section{The Statutory Notice Method Used By Internal Revenue Service}

The Internal Revenue Service (IRS) used this method to compute Chevron's deficiencies. In applying this method, the IRS first determined the Chevron's group combined pre-apportionment income. Dividend income was then divided into foreign-source portfolio dividends and other dividends. A portion of the affiliated group's deduction for the California tax was allocated to a class of gross income consisting of foreign-source portfolio dividends by multiplying such dividends by the apportionment fraction and the California tax rate. This resulted in the California tax being apportioned to the foreign-source portfolio dividend income. Next, both U.S.- and foreign-source portfolio dividends were subtracted from the pre-apportionment income of each member. Then, member-by-member, the remaining preapportionment income was compared to the member's federal taxable income, less portfolio dividends, reported on the separate corporation schedules to the corresponding return of the group. Any excess of each member's preapportionment less all portfolio dividends over reported federal domestic-source taxable income was added together and multiplied by the apportionment fraction and the California tax rate. This resulted in the deduction for the California tax apportioned to foreign-source gross income other than the foreign-source portfolio dividends. For each member, the sum of the California tax apportioned to the foreign-source portfolio dividend income and to the other foreign-source gross income portfolio dividends was the total California tax apportioned to foreign-source gross income.

\section{The Pro Rata Method Used By Internal Revenue Service}

In the Chevron case, the IRS argued that if the Tax Court disagreed with the statutory method, the court should permit the use of the pro rata method. ${ }^{25}$ The difference between the pro rata and the statutory methods is that the pro rata method does not separately allocate a portion of the state tax deduction to a class of gross income consisting solely of foreign-source portfolio dividend income. The IRS argued that under the statutory notice method a separate allocation is necessary according to the dividend rule of Reg. $\S 1.861-8(\mathrm{e})(6)(\mathrm{i})$. The pro rata method allocates the entire California tax deduction to the class of income taken into account in computing combined pre-apportionment income. Since that income includes both U.S.- and foreign-source gross income, the deduction is apportioned between the two types of income based on the respective ratios of both U.S.- and foreign-source gross pre-apportionment income to pre-apportionment income from all sources. 
The Examples Method Used By Chevron

Chevron's fallback position if the Tax Court rejected all of its other arguments was that the Service's statutory notice and pro rata methods impermissibly deviated from Reg. § 1.861-8(g), Examples 25 through 32 . Chevron argued that the underlying principle of these examples is that the state tax is allocated and apportioned to foreign-source gross income only when the sum of a corporation's state taxable income exceeds its federal U.S.-source gross income.

\section{Permissibility of Chevron's Methods}

The principal issue in Chevron was whether the taxpayer's gross income and factor operations methods were contrary to the Regulations. In support of the apportionment methods it used, Chevron claimed that Regulation $\S 1.861$ 8(e)(6)(i) implement Section 862(b) in vague terms. The Tax Court disagreed with this argument finding that the Regulations explicitly states that the deduction for state income taxes is allocable to the gross income on which such taxes are imposed. In addition, the court determined that the Regulation clearly provides that the law of the taxing jurisdiction and not federal income tax principles determines the income on which a state tax is imposed. Therefore, if a state tax is imposed in part on federal-source income, as determined under the law of the taxing jurisdiction, the taxpayer's deduction for such tax is definitely related and allocable to a class of gross income that includes foreignsource income. Yet, the Tax Court found that Regulation §1.861-8(e)(6)(i) do not specify how to determine whether a state tax is imposed on foreign-source income. The regulation does provide, however, that if a state attributes taxable income to a corporate taxpayer under a system applying combined reporting and formula apportionment, the income so determined is the income on which the state tax is imposed. The regulation further states if that income includes foreignsource income the taxpayer's deduction for the state income tax is definitely related and allocable to a class of gross income that includes the foreign-source gross income.

According to the Tax Court, for any method of apportionment to satisfy the regulations it must allocate the state tax by reference to state taxable income. This necessarily means that in a state with combined reporting and formula apportionment, a satisfactory method must begin with state taxable income as defined under local law. Since neither the gross income method nor the factor operations method began with state taxable income, the Tax Court found both methods to be inconsistent with the regulations and thus was not permitted to be used.

\section{Congressional Intent}

In Chevron, the Tax Court stated that the first consideration in determining the validity of the regulations was whether Congress unambiguously expressed its intent to prohibit the allocation of state tax under a method that takes into account combined reporting and income other than that generated by in-state operations. ${ }^{26}$ If not, the inquiry would be whether the regulation was based on a permissible construction of the Code. The Tax Court found that the Code merely requires that to determine taxable domestic and foreign source income, there must be deducted "the expenses, losses, and other deductions properly apportioned or allocated thereto and a ratable portion of any expenses, losses, or other deductions which cannot definitely be allocated to some item or class or gross income., ${ }^{27}$ Since the Internal Revenue Code does not provide specific guidance on how the relationship of a deduction to income should be determined, the Tax Court found that it was clear that Congress had not unambiguously expressed its intent, and it was necessary to determine if Regulation $\S 1.861-8(\mathrm{e})(6)$ (i) was a reasonable construction of the Code.

In deciding whether Regulation $\S 1.861-8(\mathrm{e})(6)(\mathrm{i})$ was a reasonable construction of the Code, the Tax Court found that there is a congressional mandate to determine both a taxpayer's entire taxable income and foreign-source taxable income in computing the Section 904 limit on foreign tax credits. It is necessary to determine the amount of foreign-source taxable income in order to prevent double taxation. Thus, the allocation and apportionment of state income taxes must be accurate also to prevent double taxation. Apportionment rejects geographical or transitional accounting according to the U.S. Supreme Court, which recognized that under formula apportionment, U.S.- and foreign-source income are, without differentiation as to geography, subject to state taxation. ${ }^{28}$ Yet, geography is not irrelevant to formula apportionment, since the location of a corporation's activities is key to apportionment. 
Location of income realization or, as labeled in federal income taxation, U.S.- and foreign-source income of a unitary business is of limited importance in formula apportionment. While the geographical indifference as to the source of income for apportionment purposes, Section 904 requires geographical accounting. The task is to apportion state taxes between U.S.- and foreign-source incomes the state income tax levied without regard to the source of income. ${ }^{29}$ The requirement that a deduction for income taxes should be allocated to the income on which the taxes are imposed has long been a part of federal tax law. The regulation contains a reasonable scheme of allocation and apportionment according to the court even though it contains a dichotomy. If a state excludes foreign-source income from its taxation, the resulting deduction is allocated solely to domestic-source income, but if it includes foreign-source income in its tax base, the resulting deduction is allocable in part to foreign-source income. The Tax Court found this method to be reasonable construction of the Code.

\section{Entitlement to Rely on the Examples Method}

In anticipation that the court might reject all of its other arguments Chevron argued that the Service's statutory notice and the pro rata methods impermissibly deviated from Regulation $\S 1.861-8(\mathrm{~g})$, Examples 25 through 32 . In these examples the state tax liability is allocated and apportioned to foreign-source income only when the sum of a corporation's state taxable income exceeds its federal U.S.-source taxable income. Chevron argued that the Service should not impose other methods that deviate from the principles underlying the examples in the regulations. Furthermore, if the Service were allowed to impose other method the examples in the regulations would become meaningless exercises providing no guidance. Therefore, the Service should be bound to reach the results of the examples when the facts do not materially differ from those in the examples. The Tax Court stated that if the examples were not to apply to a particular state or to a significant number of other states that use formula apportionment the regulations should state that fact.

\section{SUMMARY}

There are a number of methods for allocating state income tax expense and state franchise tax, if measured by income. The taxpayer selects whatever method; the method should optimize the taxpayer's tax objectives and should have substantial authority under the Code and Regulations. ${ }^{30}$ Taxpayers should be aware of the IRS' prescribed methods and their ability to apply another method if it yields a more accurate result. If another method is more advantageous, permission of the district director should be sought, but the accuracy of this method must be proven. In Chevron, the Tax Court held various methods failed to satisfy Regulation $\S 1.861-8(\mathrm{e})(6)(\mathrm{i})$, which explicitly states that the deduction for state income taxes is allocable to the gross income with respect to which such taxes were imposed. The income on which state tax is imposed is determined by reference to the law of the taxing jurisdiction and not federal income tax principles.

As a corporation conducts business in more states, the degree of complexity in the allocation of state income tax expense for purposes of the foreign tax credit limitation becomes exponentially more complex. The aggregate amount of state income and franchise taxes represents one of the corporation's major expenses. Since many corporations have excess foreign tax credits, the IRS is aware that corporate taxpayers would like to maximize their foreign-source income and minimize expenses that are allocated to such income. Upon audit, it would be expected that the IRS would pay extra attention to a taxpayer's calculation of the allowable foreign tax credit.

\section{AUTHOR INFORMATION}

Robert M. Kozub, DBA, CPA, is an Associate Professor of Accounting and Taxation in the Sheldon B. Lubar School of Business at the University of Wisconsin-Milwaukee. He is Lawrence G. Regner Fellow in Accounting and Taxation as well as a Faculty Fellow in the Deloitte \& Touche Multistate Tax Center at the University of Wisconsin-Milwaukee. He earned his Doctor of Business Administration degree at the University of Kentucky and is a certified public accountant licensed in Wisconsin. Dr. Kozub has published over 120 articles in scholarly and professional journals and has co-authored three books and contributed to others. 


\section{REFERENCES}

${ }^{1}$ A resident alien is an individual who resides in the United States, but is not an U.S. citizen.

${ }^{2}$ IRC $\$ \S 7701(a)(3)$ and (4) defines a domestic corporation as a corporation created or organized under federal law or the laws of one of the 50 states or the District of Columbia. All other corporations are defined as foreign corporations. Under the check-the-box regulations, a domestic corporation also can include a non-corporate entity that elects to be taxed as a corporation.

${ }^{3}$ U.S. possessions include, for Sec. 901 purposes, Puerto Rico, the Virgin Islands, Guam, the Northern Marina Islands, and American Samoa.

${ }^{4}$ Authority for this method is found in old Reg. $§ 1.861-8(\mathrm{~g})$. See Examples 25 and 26 of old Reg. $§ 1.861-8$ (g) and Examples 25 through 29 of new Reg. § 1.861-8T(g).

${ }^{5}$ Private Letter Ruling 8321008.

${ }^{6}$ Regulation Section 1.861-8(e)(6)

${ }^{7}$ Regulation Section 1.861-8(e)(6)

${ }^{8}$ Private Letter Ruling 8321008

${ }^{9}$ Regulation Section 1.861-8(e)(6)

${ }^{10}$ I.R.C. $§ 904(a)$

${ }^{11}$ See Regulation Section 1.861-8, Examples 25 and 26.

${ }^{12}$ Revenue Ruling 87-64, 1987-2 CB 167

${ }^{13}$ Revenue Ruling 87-65, 1987-2 CB 173

${ }^{14}$ Regulation $\S 1.861-8$.

${ }^{15}$ Regulation $\$ 1.861-8(\mathrm{~g})$, Examples 25 through 29

${ }^{16}$ Regulation $\$ 1.861-8(\mathrm{e})(6)$

${ }^{17}$ Revenue Ruling 79-186, 1979-1 CB 238

${ }^{18}$ Regulation $\$ 1.861-8(\mathrm{e})(6)$

${ }^{19}$ Regulation $§ 1.861-8(\mathrm{e})(6)$, Example 25

${ }^{20}$ Regulation $\S 1.861-8(\mathrm{~b})(1)$

${ }^{21}$ Regulation $\S \S 1.861-8(\mathrm{a})(2)$, and 1.861-8(b)(2)

${ }^{22}$ Regulation $\S 1.861-8(\mathrm{e})(6)(\mathrm{i})$

${ }^{23}$ In Alabama, Arizona, Hawaii, Kansas, Maine, Minnesota, Nebraska, New Hampshire, Oklahoma, Oregon, and Tennessee, a unitary business must file either a combined report or a consolidated. However, in California, Colorado, Idaho, Illinois, Montana, North Dakota, and Utah, a unitary business must file a combined report or a consolidated return; these corporations may make a water's edge election, thus effectively limiting the reach of the state's taxing authority to activities occurring within the boundaries of the United States. Unitary businesses can elect to file a combined report in Georgia, Kentucky, New Mexico, and New York, and in addition to this election, unitary businesses in Indiana and Ohio can make the water's edge election. In Arkansas, Iowa, Florida, Massachusetts, Mississippi, Missouri, Rhode Island, South Carolina, Vermont, Virginia and West Virginia a unitary business is allowed to file a consolidated return.

${ }^{24}$ Chevron Corporation v Commissioner, 104 TC 719 (1995)

${ }^{25}$ Chevron Corporation v Commissioner, 104 TC 719 (1995)

${ }^{26}$ See NationsBank v. Variable Annuity Life Insurance Co., 115 S.Ct. 810 (1995).

${ }^{27}$ IRC $\S$ 861(b) and 862(b).

${ }^{28}$ Barclays Bank v. California Franchise Tax Board, 463 U.S. 159 (1983)

${ }^{29} \mathrm{Id}$.

${ }^{30}$ IRC $\S 6661$ 